\title{
EGYPTIAN ADOPTED PLASTIC CURD CHEESE VARIETIES, PROVOLONE, MOZZARELLA, MEDAFFARAH AND HALLOUMI : AN OVERVIEW
}

\author{
Abou-Donia, S.A. \\ Dairy Science and Technology Dept., Fac. of Agric., Alexandria Univ., Alexandria, 21545, Egypt.
}

\begin{abstract}
Egyptian adopted provolone, mozzarella, medaffarah, halloumi and kashkaval are the most popular cheese varieties belonging to plastic curd or "Pasta filata" cheese varieties which originated in Italy, Eastern European and Balkan Peninsula and Middle Eastern countries. In Egypt, the previous cheese varieties are adopted and produced.

This review considers the manufacture process, milk used, different additives to milk on chemical composition, microbiological, rheological, and organoleptic properties of provolone, mozzarella, medaffarah and halloumi cheese varieties.
\end{abstract}

Keywords: Egyptian plastic curd cheese, provolone cheese, mozzarella cheese, medaffarah cheese, halloumi cheese.

\section{INTRODUCTION}

Plastic curd or "Pasta filata" cheese family consists of a large distinguished cheese varieties produced mainly in Italy, Eastern European and Balkan Peninsula, and Middle Eastern Arab countries.

Plastic curd cheeses are characterized by a unique placticizing and kneading treatment of fresh curd in hot water, which acquires the finished cheese its characteristic fibrous structure, melting and stretching properties, high elasticity and free of lumps.

In Egypt, some plastic curd cheese varieties are adopted and produced with some slight modifications in the manufacturing process, therefore it is considered local Egyptian adopted cheese varieties, such as Egyptian provolone, mozzarella, medaffarah, haloumi and kashkaval. The production of the plastic curd cheese was highly increased in all of the Egyptian provinces during the last decade because the fresh curd after kneading treatment in hot water of the above cheese varieties could be utilized as a topping on pizza, but the most known one in that concern is mozzarella cheese.

The Egyptian kashkaval cheese which is known in small private dairy plants in Damietta city as "Gebnet el tassieh" or melting cheese, was recently reviewed by AbouDonia (2004).
Therefore the present article reviews the Egyptian provolone, mozzarella, medaffarah and hallonmi adopted cheese varieties.

\section{Egyptian provolone cheese}

Provolone cheese is a cheese variety of the pasta filata family, which has its origin in southern Italy, probably in Sicily. Provolone cheese originated in Egypt by the Italian emigrants in Alexandria and now it is consumed and manufactured in many Egyptian provinces. Egyptian provolone was first investigated by El-Soda (1973) and then by Soliman, Nahed (1979).

\section{Cheese manufacturing}

A suitable amount of rennet is added to raw milk so as to obtain a good firm curd within one hour. The curd is then cut and left in the whey for approximately $15 \mathrm{~min}$ after which the whey is removed and the curd transferred to a cloth-lined round metal hoop and left for 2-3 hr.

The curd is then cut into small pieces and left at room temperature until the curd gave the proper test in hot water. The test is made by dipping a piece of curd in hot water bath at $79.3^{\circ} \mathrm{C}$ for a few seconds, thereafter it is twisted and stretched slowly into a fine thread a yard long without tendency to break. If the test is positive, the curd is ready for shaping. 
The shaping is done by dipping the curd in hot water bath at $79.3^{\circ} \mathrm{C}$ until it becomes more elastic, then it is shaped by hand to a suitable ball form. The balls are then dipped in $20 \%$ salted whey solution for $24 \mathrm{hr}$, and then placed in a rope net which is hanged from the ceiling, after $24 \mathrm{hr}$ the smoking procedure is accomplished by exposing the cheese to the smoke of burning wood in a half cut barrel.

The smoked cheese is placed in a ripening room at $10^{\circ} \mathrm{C}$ to $12^{\circ} \mathrm{C}$ for 4 weeks (ElSoda and Abou-Donia, 1981).

\section{Milk used for preparation of provo- lone cheese}

Abdel-Rafee and Abdel-Gawad, Mona (2002) manufactured provolone cheese from standardized buffalo's, cow's and goat's milk (4\% fat) and from their mixtures (1:1). The produced cheeses were stored for 3 months at $15^{\circ} \mathrm{C}$.

The cheese yield was the highest for buffalo's milk cheese and the lowest for goat's milk cheese. Soluble nitrogen, soluble tyrosine and soluble tryptophan of buffalo's milk cheese were less than those in cow's and goat's milk cheese. Mixing cow's or goat's to buffalo's milk increased the soluble, nitrogen, tyrosine and tryptophan contents and improved the firmness, flavour, body and texture of provolone cheese.

\section{Chemical composition of provolone cheese}

El-Soda et al (1976a) found that the buffalo's milk cheese had the following composition after a ripening period of 4 weeks, moisture $31.0 \%$, fat $36.50 \%$, total protein $20.25 \%$, soluble protein $2.30 \%$. The $\mathrm{pH}$ was found to be 5.47. For cow's milk cheese these values were $34.09 \%$, $30.00 \%$, $24.10 \%$, 3.30\% and 5.4, respectively.

\section{Microbiology of provolone cheese}

El-Soda et al (1976c) reported that the gram positive and catalase positive cocci disappeared from all the provolone cheese, samples analysed after the smoking process, leaving a flora consisting mainly of lactic acid bacteria. The streptococci represented $56 \%$ of the isolates in the ripened cheese. Streptococcus faecalis was found to be the predominant species among the isolated streptococci.

\section{Ripening of provolone cheese}

El-Soda et al (1976b) found that acetic acid was detected during all the stages of the manufacturing process of provolone cheese, while propionic, butyric, caproic and caprylic acids appeared after the ripening period. They also noticed that butyric acid in cheese obtained from buffalo's milk, appeared at the early stages of manufacture.

\section{Egyptian mozzarella cheese}

Mozzarella cheese is a soft, unripened cheese variety of the pasta filata family, which had its origin in the Buttipaglia region of Italy. The finished cheese is lightly, white, soft, with a very lively sheen surface and has a unique property called strechability to form fibres or strings when it is hot, therefore it is considered the most suitable cheese variety as a topping on pizza. (Kosikowski, 1970).

Mozzarella cheese originated in Egypt by the Italian emigrants in Alexandria city, and now it is consumed and manufactured in many of the Egyptian provinces. Egyptian mozzarella was first investigated by Anis \& Ladkani (1988).

\section{Cheese manufacturing}

Raw milk is pasteurized at $72^{\circ} \mathrm{C} / 15 \mathrm{sec}$. cooled at $35^{\circ} \mathrm{C}$, and $0.02 \% \mathrm{CaCl}_{2}$ is added, then $1 \%$ starter is added until $\mathrm{pH} 6.1$ reached in about $20-30 \mathrm{~min}$. or cooled at $10^{\circ} \mathrm{C}$, and $0.02 \%$ $\mathrm{CaCl}_{2}$ is added, then direct acidification with lactic or acetic or citric acid until pH 5.8, warming the milk at $35^{\circ} \mathrm{C}$ and $0.002 \%$ rennet powder is added. The coagulum is cut and scalding at $42^{\circ} \mathrm{C}$ for $20-30 \mathrm{~min}$ till $\mathrm{pH} 5.8$. The whey is drawn off and cheddaring the curd at $42^{\circ} \mathrm{C}$ until $\mathrm{pH}$ 5.4. Curd is milled/ kneaded in hot water and moulded at $85^{\circ} \mathrm{C}$, cooled and salted in saturated brine (23\%) for $5 \mathrm{hr}$ at $4-6^{\circ} \mathrm{C}$.

The cheese is removed from brine, drying the surface, and warp, packed in polyethylene bags. The cheese is stored by cooling in refrigerator at $4^{\circ} \mathrm{C}$ or freezing in a deep freezer at $18^{\circ} \mathrm{C}$ (Kosikowski, 1970).

The curd may taken in the hand, kneaded and pulled to form cord, every three cords are formed in braid shape, the tress of cheese is cut in pieces about $8 \mathrm{~cm}$ long for each as Syrian medaffarah cheese (Abou-Donia \& Abdel Kader, 1979). 


\section{Improvement of the manufacture process}

Several attempts were tried to modify the manufacture process of the Egyptian mozzarella cheese.

\section{Milk used}

Buffalo's milk: It is the most suitable milk for the manufacture of mozzarella cheese in Egypt (Mostafa et al., 1996, Abd El-Raffee et al., 1998a,b, Abd El-Hamid et al., 2004, Abed El-Aziz, 2004, El-Safty et al., 2004).

Cow's milk: Anis \& Ladkani (1988), Mostafa et al. (1996), Abd El-Hamid et al. (2001a), Abed El-Aziz (2004) and El-Safty et al. (2004).

Goat's milk: Mostafa et al. (1996) and Abed El-Aziz (2004).

\section{Starter addition to milk}

The addition of starter to pasteurized milk prior the manufacture was considered. Hassan, Fatma (2000) manufactured round shape mozzarella cheese using different ratios of coccus to rod starter culture i.e. Streptococcus salvarius sub. thermophilus + Lactobacillus delbruckii sub. bulgaricus (1:1) and $S$. salvarius sub.thermophilus $+L$. helveticus (1: 10). The coccus to rod ratio did not affect the gross composition of cheese, while cheese manufactured using 1: 10 coccus to rod ratio showed higher content of ripening indices than other treatment during cold storage for 4 weeks, also the same treatment gave the highest acidity, meltability, oiling off and the lowest $\mathrm{pH}$ when fresh and during cold storage for 4 weeks than other treatments. Abed-El Aziz (2004) used yoghurt starter (S. thermophilus + L.bulgaricus) in the manufacture of mozzarella cheese and obtained similar results.

\section{Effect of milk type, homogenization, ultrafiltration and standardization of milk fat, acidulants, and different ad- ditives to milk on chemical composi- tion, microbiological, rheological and organoleptic properties and micro- structure of mozzarella cheese.}

Milk type: Mozzarella cheese made from buffalo's milk showed lower content of soluble and non-soluble protein nitrogen, soluble tyrosine and tryptophan and total volatile fatty acids than cheese made from cow's and goat's milks. After 4 weeks of storage, marked proteolysis in $\alpha_{s}$-casein and $\beta$-casein was detected in mozzarella cheese for all of buffalo's, cow's and goat's milks used. Mixing of cow's milk with buffalo's milk highly improved the quality of the cheese. (Mostafa et al., 1996, El-Battawy et al, 2004b).

Homogenization of milk: Homogenization of milk for mozzarella cheese manufacture tended to increase firmenss and decreased oiling off, fat leakage and meltability. The microstructure of cheese showed that low fat cheese tends to be harder more crumbly and less smooth than normal. (Abdel-Rafee et al., 1998a, El- Battawy et al., 2004b).

Ultrafiltration of Milk: El- Battawy et al. (2004a) manufactured mozzarella cheese from buffaloes, cows milk and their mixture (1:1) and from the same kinds of milk but after concentration by ultrafiltration (concentration factor, .75). The cows' milk mozzarella cheese tended to be softer, slightly better in flexibility and contained slightly higher moisture, fat, and salt contents whereas buffalo's milk mozzarella cheese had higher protein content.

Standardization of milk fat: Badawi et al. (2004b) found that mozzarella cheese made from low fat milk (1.5\% fat milk) had elongated protein matrix and contained few channels between protein strands and was firm and rubbery texture, while cheese made from $4.5 \%$ fat had a sponge like appearance and was more pitted. Addition of sodium caseinate intensified casein matrix. During cheese storage the spherical shape of the fat globules was clearly defined, surrounded by the loose protein matrix.

Acidulants: Milk was direct acidified for mozzarella cheese manufacture. Inorganic acids as hydrochloric and phosphoric acid (Anis \& ladkani, 1988), and organic acids as lactic, acetic and citric acids (Abed El-Aziz, 2004) were used for that purpose. Positive relationship was found between the calcium content of the curd and its rheological properties.

Protein concentrates: Addition of $1 \%$ of soy protein concentrates, particulated whey proteins (Dairy-Lo) or sodium caseinate to milk for mozzarella cheese manufacture, gave cheese with acceptable organoleptic properties (Hassan, Fatma \& Abd El-Gawad, Mona, 2000).

Fat Replacers: Cow's milk fat was partially replaced by novagel, Dairy-Lo or malto dextrin for mozzarella cheese making. Addi- 
tion of fat replacers enhanced the meltability, lowered oiling off, and improved the microstructure of cheese (Abd El-Hamid et al. (2001a).

Food additives: Mozzarella cheese was made with the addition of trisodium citrate, sodium carboxy methyl cellulose, and sodium caseinate to the cheese milk ( $1.5 \%$ that) at the rate of $0.1,0.1$ and $1.0 \%$, respectively. The resultant cheese exhibited higher meltability and lower oiling off. The addition of $\mathrm{Na}$ citrate gave cheese with fibrous structure and spongy protein matrix (Abd El-Hamid et al., 2001b).

Calcium chelating agents: Calcium chelating agent was added to buffalo's milk used for mozzarella cheese to overcome the high calcium content of that milk and thereby its resultant cheese. The cheese rheological properties were enhanced, while the microstructure became better concerning protein solubility with much more fibres and open structure. (Abd El-Hamid et al. (2004).

Sodium caseinate: Badwi et al. (2004a) manufactured mozzarella cheese from milk fortified with $0,1,2$ and $3 \%$ sodium caseinate. The above treatment increased significantly the acidity, SN. soluble tyrosine, soluble tryptophan contents and scores of the organoleptic properties, while it decreased significantly $\mathrm{pH}$ values and total volatile free fatty acids in the resultant cheese.

Soy milk: The manufacture of low moisture mozzarella cheese from blends of soy milk and cow's or buffalo's milk was investigated, meltability and stretchability of cheese decreased and leakage as the proportion of soy milk increased (El-Safty et al., 2004).

Coagulating enzymes: Mozzarella cheese was made from buffalo's milk using three types of coagulants, calf rennet, mucor miehi rennet and chymosin. The mucor miehi had the ability to resist high temperature during streching process (Abdel-Rafee et al., 1998b).

\section{Chemical composition of mozzarella cheese}

Mean chemical composition of local fresh mozzarella cheese collected from Mansura city markets was as follows: fat 20.50, total protein 49.55, total solids, 49.55 and acidity $0.35 \%$. (Abed-El-Aziz, 2004).

\section{Microbiological quality of mozzarella cheese}

Abed El-Aziz (2004) reported that local fresh mozzarella cheese samples collected from Mansura city markets were free from coliforms and Staphylococcus aureus.

\section{Manufacture of processed mozzarella cheese}

Low-fat processed cheese spread was successful made with incorporating low fat mozzarella cheese in the base blend (Awad et al., 2003).

\section{Egyptian medaffarah cheese}

Medaffarah or majduala cheese is a soft, unripened cheese variety of the pasta filata family. It is traditionally home made cheese in the Middle Eastern countries such as Syria, Labanon, Jordan and Palestine. Also, it is manufactured in Egypt in Alexandria city in small private dairies. Medaffarah cheese is considered the similar cheese variety to mozzarella cheese.

\section{Cheese manufacturing}

The medaffarah or majdula or braided cheese is manufactured in Alexandria, Egypt and Aleppo (Haleb), Syria by the same method as described by Abou-Donia \& Abdel-Kader (1979) as follows:

Milk is renneted at $35^{\circ} \mathrm{C}$ in galvanized tins and coagulated within 4 hrs. The coagulum is put in cheese clothes bags in about 1 $\mathrm{Kg}$ quantities, well tighted, left about 8 hrs for whey drainage, then the coagulum is cut to pieces about $15 \mathrm{X} 15 \mathrm{X} 3 \mathrm{~cm}$. A weight equal to that of the curd is put on top of the cheese cloth and left for nearly 24 hrs for the curd to develop acidity and ripen.

Ripening is assessed by taste a piece of curd which is warmed at $75^{\circ} \mathrm{C}$. The curd is then taken in the hand, kneaded and pulled to form a cord of four meters long. If it breaks before reaching this length, then the ripening is not completed.

When the curd is ripe, it is cut into smaller pieces $3 \times 3 \times 3 \mathrm{~cm}$., put in perforated separator, warmed in water at $75^{\circ} \mathrm{C}$ for about 3 minutes (high amount of fat is lost), the curd is then taken in the hand, kneaded and pulled to form a cord, every three cords are 
formed in braid shape, the tress of cheese are cut in pieces about $8 \mathrm{~cm}$ long for each.

The cheese tress are immersed in saturated brine at room temperature for about 1 week. Finally the salted cheese tress removed from brine, exposed to the sun to dry for 2 or 3 days, then held in tight containers until used. They are eaten after being soaked in water for 24 hrs. (Abou-Donia \& Abdel-Kader, 1979).

\section{Milk used for the preparation of pro- volone cheese}

In Egypt, buffalo's, cow's and sheep milks are used for the manufacture of medafarah cheese, while in Syria only the sheep milk is used for medaffarah or majdula cheese manufacturing in the period from March to July, when the herds move up from the valleys to the mountains and milk production is at its peak. Most of sheep's milk in Syria is produced from Awassi breeds, which represents about $80 \%$ of the Syrian Sheep. (Abou-Donia \& AbdelKader, 1979).

\section{Chemical composition of medaffarah cheese}

Abou-Donia \& Abdel-Kader (1979) found that the chemical composition of medaffarah cheese was as follows: Moisture, 28.63\%, fat/DM. 27.10, protein 35.60, ash 6.70, salt 5.55\%, and $\mathrm{pH} 5.0$.

\section{Microbiology of medaffarah cheese}

Abou-Donia \& Abdel-Kader (1979) reported that the microbial counts of medaffarah cheese as CFU/gm was as follows, total count $2.05 \times 10^{5}$, proteolytic microorganisms, $1.6 \times 10^{4}$, lipolytic microorganisms, $1.4 \times 10^{4}$, yeasts and moulds $1.8 \times 10^{2}$. The examined cheese samples were found to be completely free from coliforms.

\section{Egyptian halloumi cheese}

Halloumi cheese is the traditional cheese of Cyprus and for many years, it has been produced from sheep's milk, goat's milk or their mixture (Anifantakis \& Kaminarides, 1981). Halloumi cheese is widely popular throughout the Middle Eastern countries such as Syria, Lebanon, Jordan and Palestine. It is also produced in Alexandria city in small private dairies. The Halloumi cheese is a cheese variety of pasta filata family.
Halloumi cheese is semi-hard to hard elastic, has no obvious skin/rind and the texture is close with no holes and it is easily sliced.

Halloumi cheese can be consumed raw, but it is usually grilled, fried or grated over hot dishes.

\section{Cheese manufacturing}

Raw milk is coagulated with rennet at $34^{\circ} \mathrm{C}$ within $7-8 \mathrm{~min}$. The curd is cutting to 0.5 $\mathrm{cm}^{3}$ grains, rest for $1 \mathrm{hr}$, gentle stirring for 10 min., heating to $45^{\circ} \mathrm{C}$ within 20 min and holding for further $40 \mathrm{~min}$, stirring after heating for $20 \mathrm{~min}$. The whey is drawn off, heated to $80^{\circ} \mathrm{C}$, the curd pressed $\left(7 \mathrm{Kg} / \mathrm{Kg}^{-1}\right)$ of curd for $1 \mathrm{~h}$, then the curd is transferred to hot whey and continuous heating of the whey and curd for $1 \mathrm{hr}$. (Cooking the curd). Then drainage of cooked pieces of curd on cheese table for cooling to $30^{\circ} \mathrm{C}$, salting in brine solution $10 \%$ for $30 \mathrm{~min}$ and finally addition of fresh or dried Baladi mint leaves (Mentha viridis). Next day packed into polyethylene bags, or conserved in brine. (Robinson, 1991).

\section{Improvement of the manufacture process}

The knowledge about the improvement of the manufacture of Halloumi cheese should be based dependent on the two excellent research papers of Abdou, Sania et al., 2002 and 2003.

\section{Halloumi cheese from different types of milk}

Abdou, Sania et al. (2002) reported that halloumi cheese was successfully made from cow's, buffalo's milk and their mixture at ratio $1: 1$. The yield of the produced cheese was calculated as it was 15.26 and 12.24 in previous order. Halloumi cheese of both of the two milks or from their mixture had close score, however, halloumi cheese made from cow's milk gained the lowest score.

\section{Low fat halloumi cheese}

Abdou, Sania et al. (2003) manufactured low fat halloumi cheese from half-fat milk heated to $76^{\circ} \mathrm{C} / 5 \mathrm{~min}$, with adding $2 \mathrm{~g} 100^{-}$ ${ }^{1} /$ fat replacer (Simplesse ${ }^{\circledR} 100$ ) and compared it with full-fat halloumi cheese made from mixture cow's and buffalo's milk (1:1). The sensory evaluation of halloumi cheese made from low fat mix with fat replacer gained high score close to the control cheese score. 


\section{Chemical composition of halloumi cheese}

Abdou, Sania et al (2002) found that the chemical composition of halloumi cheese manufactured from cow's, buffalo's and mixed milks was as follows: moisture 43.04, 41.83 and 41.35, fat/DM 49.15, 59.60 and 55.12, protein, 18.33, 23.40 and 20.70 , salt 1.22, 1.28 and 1.10, ash 4.76, 5.66 and 4.75, acidity $0.23,0.28$ and $0.21 \%$, respectively.

\section{Microbiological quality of halloumi cheese}

Abdou, Sania et al. (2002) reported that the viable count $\mathrm{CFU} / \mathrm{gm}$ of halloumi cheese manufactured from cow's, buffalo's and mixed milks was, total viable count $2.6 \times 10^{3}$, $1.7 \times 10^{3}$ and $1 \times 10^{3}$, yeasts and moulds $2 \times 10^{2}, 20 \times 10^{2}$ and $12 \times 10^{2}$, respectively. Coliforms were not detected in the three treatments. Although the high temperature during cooking the curd is enough to kill most of microorganisms but the presence of viable bacteria, yeasts and mould may be due to the contamination during handling and packaging and adding of mint and salt to the cheese.

\section{REFERENCES}

Abd-El-Hamid, L.B., Hagrass, A.E, Awad, R.A. \& Zammar O.A. 2001a. Physical and sensory properties of low calorie mozzarella cheese with fat replacers. Proc. $8^{\text {th }}$ Egyptian Conf. For Dairy Sci. \& Technol. Dokki 3-5 Nov. 2001, Cairo, Egypt. Part I pp. 283-298.

Abd-El-Hamid, L.B., Hagrass, A.E, Awad, R.A. \& Zammar O.A. 2001b. Physical and sensory properties of low calorie mozzarella cheese with some food additives. Proc. $8^{\text {th }}$ Egyptian Conf. For Dairy Sci. \& Technol. Dokki 3-5 Nov. 2001, Cairo, Egypt. Part I pp. 299-315.

Abd-El-Hamid, L.B., Awad, R.A. Zedan, M. \& Salama, Waffaa, M. 2004. Improving functional properties and texture of buffalo mozzarella cheese using calcium chelating agents. Proc. $9^{\text {th }}$ Egyptian Conf. For Dairy Sci. \& Technol. Dokki 9-11 Oct. 2004, Cairo, Egypt. Part II pp. 461-475.

Abdel-Rafee, S. \& Abdel-Gawad, Mona, A.M. 2002. Effect of milk types on the properties of provolone cheese. Egyptian Journal of Dairy Science, 30(2): 243-252.

Abdel-Rafee, S., Ahmed , Nawal, S., El-Abd, M.M. \& Abdel-Kader, Mona 1998a. Buffalo's mozzarella cheese I. Effect of homogenization on the properties and microstructure of cheese. Proc. $7^{\text {th }}$ Egyptian Conf. For Dairy
Sci. \& Technol. Dokki 7-9 Nov. 1998, Cairo, Egypt. Abstract p. 309.

Abdel-Rafee, S., Ahmed , Nawal, S., El-Abd, M.M. \& Abdel-Kader, Mona 1998b. Buffalo's mozzarella cheese II. Effect of stretching on coagulating enzymes. Proc. $7^{\text {th }}$ Egyptian Conf. For Dairy Sci. \& Technol. Dokki 7-9 Nov. (1998b), Cairo, Egypt. Abstract p. 312.

Abdou, Sania. M., Shenana, M.E., Osman, S.C. \& Sadek, A.M. 2002. Production of Halloumi cheese from different types of milk. Egyptian Journal of Dairy Science, 30: 231.

Abdou, Sania. M., Shenana, M.E., Osman, S.G. \& Sadek, A.M. 2003. Production of low-fat Halloumi cheese. Egyptian Journal of Dairy Science, 31: 101-110.

Abed El-Aziz, M.E. 2004. Studies on Mozzarella Cheese. M.Sc. Thesis, Dairy Sci., Fac. of Agric. Mansura University.

Abou-Donia, S.A. 2004. Developments in Egyptian kashkaval cheese: An overview article. Alexandria Journal of Food Science and Technology 1(1): 69-73.

Abou-Donia, S.A. \& Abdel-Kader, Y.I. 1979. Microbial flora and chemical composition of native Syrian hard cheese "Mesanarch", "medaffarah", and "shankelish". Egyptian J. Daiy Sci. 7: 221-229.

Anifantakis, E.M. \& Kaminarides, S.E. 1981. Contribution to the study of Halloumi cheese. Journal of Agricultural Research, 5: 441.

Anis, S.M.K. \& Ladkani B.G. 1988. Effect of kind of acidhulant and $\mathrm{pH}$ level on some characteristics of mozzarella cheese curd made by direct acidification Egyptian Journal of Dairy Science, 16(2): 267-276.

Awad, R.A, L.B. Abd El-Hamid, A.E. Haggras \& Zammar, O.A. 2003 Rheological and sensory properties of low-fat processed cheese spread with low fat mozzarella cheese in the base blend. Egyptian Journal of Dairy Science, 31(2): 361-374.

Badawi, R.M., Zedan, A.N., Okasha, A.I. \& Omara, G.M. 2004a. Changes in chemical composition and sensory properties of low fat mozzarella cheese during storage. Egyptian Journal of Dairy Science, 32:327-340.

Badawi, R.M., Farag I., Okasha, A.I. \& Omara, G.M. 2004b. Changes in theological properties and microstructure during storage of low fat mozzarella cheese. Egyptian Journal of Dairy Science, 32:34 1-353.

El-Batawy, M.A., Galal, E.A., Morsy, M.A. \& Abbas, Kh. 2004a Utilization of ultrafiltration technique in making mozzarella cheese from different kinds of milk. Egyptian Journal of Dairy Science, 32:303-314.

El-Batawy, M.A., Galal, E.A., Morsy, M.A. \& Abbas, Kh. 2004b. Effect of homogenization of some properties of mozzarella cheese Egyptian Journal of Dairy Science, 32: 315326. 
El-Safty, M.S., Gouda, A.M., Abbas, F.M., Osman, S.G. \& Hassanein, A.M. 2004. Mozzarella cheese manufactured from blends of soy milk and cow's or buffalo's milk. Proc. The $9^{\text {th }}$ Egyptian Conf. For Dairy Sci. \& Technol. Dokki, 9-11 Oct. (2004), Cairo, Egypt Part II pp. 445-460.

El-Soda, M.A. 1973. Chemical and Microbiological Studies on Provolone Cheese. M.Sc. Thesis, Dairy Science, Fac. of Agric., Alex. Univ., Alex. Egypt.

El-Soda, M.A \& Abou-Donia, S.A. 1981. Provolone cheese. A Review. Indian Journal of Dairy Science, 34 (2): 131-135.

El-Soda, M.A., El-Hagarawy, I.S., Rakshy, S.E.S.E, \& Abou-Donia, S.A 1976a. Studies on provolone cheese. I. Chemical composition. Indian Journal of Dairy Science, 29(1): 18- 21.

El-Soda, M.A., Abou-Donia, S.A., Rakshy, S.E.S.E, \& El-Hagarawy, I.S. 1976b. Studies on provolone cheese. II. Changes in volatile fatty acids during processing and ripening. Indian Journal of Dairy Science, 29(2): 88-90.

El-Soda, M.A., Abou-Donia, S.A., Rakshy, S.E.S.E, \& El-Hagarawy, I.S. 1976c. A note on some microbiological aspects of provolone cheese. Indian Journal of Dairy Science, 29(2): 137137.
Hassan, Fatma, A.M. 2000. Effect of mixed coccus and rod starter ration on mozzarella cheese quality. Egyptian Journal of Dairy Science, 28(2) 219-230.

Hassan, Fatma, A.M \& Abd El-Gawad, Mona, A.M. 2000. Manufacture of mozzarella cheese supplemented with different protein concentrates. Egyptian Journal of Dairy Science, 28(1): 37- 48.

Kosikowski, F.V. 1970 "Cheese and Fermented Milk Products” $2^{\text {nd }}$ edn., Edwards Brothers Inc., Am. Arbor, Michigan, USA.

Mostafa, M.B.M., Shahein, Nadia, M., Abdel-Kader Y.I. \& El-Zoghhy A.S. 1996. Properties of mozzarella cheese as affected by milk type. II. Proteolysis, physical properties and organoleptic quality of cheese. Egyptian Journal of Dairy Science, 24(2): 289: 296.

Robinson, R.K. 1991. Halloumi Cheese: the Product and its Manufacture. In Feta and Related Cheeses. eds Robinson, R.k. \& Tamime, A.Y. Ellis Horwood Ltd, London.

Soliman, Nahed, S. 1979. Provolone Cheese Made From Buffalo's Milk by Different Milk Clotting Enzymes and lipase. M.Sc. Thesis, Dairy Science, Fac. of Agric., Alex. Univ., Alex. Egypt.

\section{أصنــاف الجــبن المصـرى المطوعـة مرنــة الخــثرة البروفولون، الموزاريللا، المضفرة والحلومى: نظرة شامله

\author{
أد.سعمير ألمد ألبو نيا \\ قمم علوم وتكنولوجيا الألبان - كلية الزراعة - جلمعة الإبكندرية
}

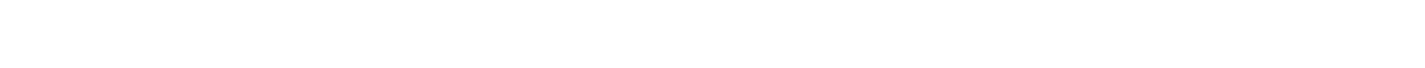

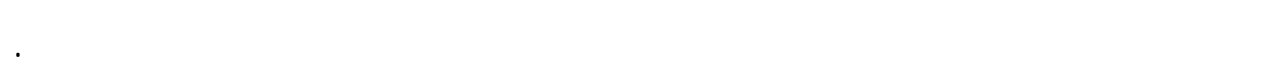

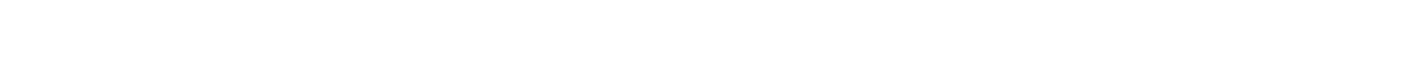

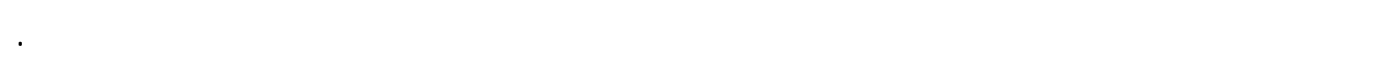

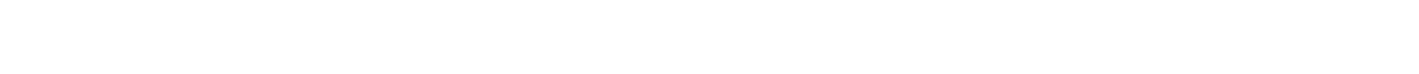

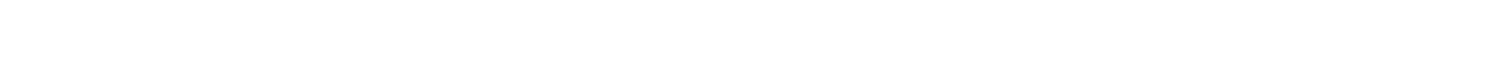

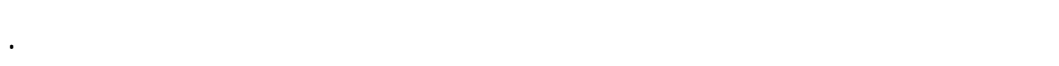


